\title{
KONSTRUKSI AYAT - HADITS EKONOMI DI MEDIA CETAK
}

\author{
Amelia Rahmi \\ Jurusan KPI Fakultas Dakwah dan Komunikasi UIN Walisongo \\ Email:ameliarahmi770@yahoo.co.id
}

\begin{abstract}
$A$ ccording to Islam, poverty is a serious problem that should be given serious solution as well. Hence Islam explained the problem of poverty an social inequality in detil, both in the aspect of conception and real solution. The article examines the construction verses and hadiths about economiy contained in Nurul Hayat magazine. By applying semiotic analysis of Roland Barthes to study of Nurul Hayat magazine on February 2015, result show that Nurul Hayat implement Islamic pattern in constructing news and articles. Al-Qur'an verses that are relevant to the theme most of them written with Latin letters and explanation given meaning by Indonesia and simple style of delivery, but for economy hadith, besides written with Arabic letters plus the means. Accurate references, credible source in explaine that theme. Thus, seem that the message was not revealed various meaning, but focusing on the understanding. In addition Nurul Hayat wrote that news and article with prescriptive description, enriched with illustration of famous preacher like Syech Ali Jaber. Charity organized in the dawn of Islam have also been known since the first Java Community with "sedekah laut" and "sedekah bumi". It was an expression of gratitude to the Almighty God of his success.
\end{abstract}

Keywords: constructs, verse-hadith, economy, magazine, semiotic

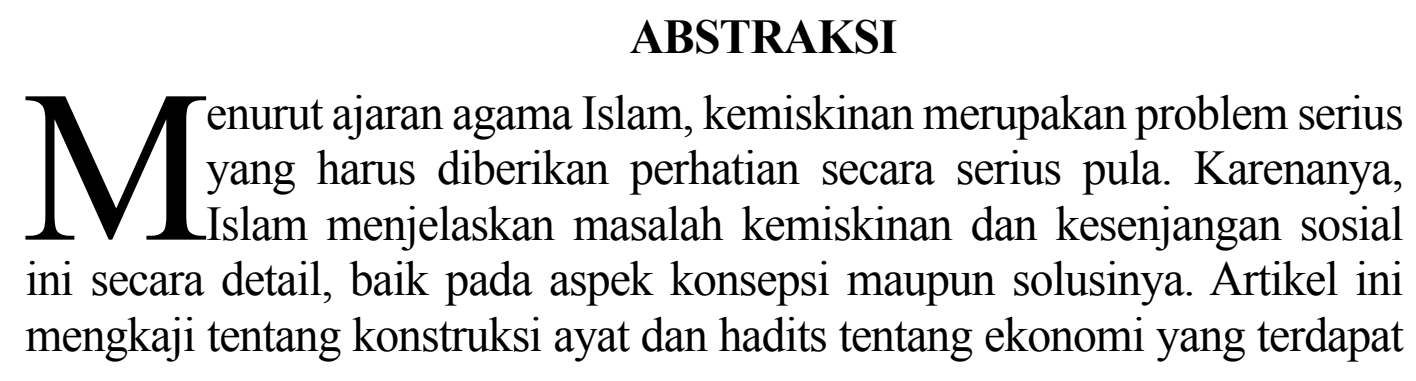


dalam Majalah Nurul Hayat. Dari penelitian terhadap majalah Nurul Hayat edisi Februari 2015 dengan menerapkan analisis semiotik model Roland Barthes, diperoleh hasil, majalah Nurul Hayat dalam mengkonstruksi berita maupun artikel mengimplementasikan pola informasi Islami. Ini terlihat dari penggunaan sumber yang jelas, rujukan yang tepat dan gaya penyampaian yang santun. Selain itu dalam menuliskan tema headline dengan pilihan kombinasi antara jenis Banner Headline dengan jenis Spread Headline yang diberi nuansa seni dan ukuran huruf yang mencerminkan sifat tegas/ kuat dan artistik. Ayat suci al Qur'an yang relevan dengan tema kebanyakan ditulis dengan huruf Latin dan diberikan penjelasan makna dalam Bahasa Indonesia, serta gaya penyampaian yang sederhana. Namun untuk hadits ekonomi juga ditulis dalam bentuk tulisan Arab (asli) ditambah terjemahan.

Selain itu, berita diperkaya dengan ilustrasi tausiyah dai kodang yang kredibel,dan bersifat preskriptif. Sedekah subuh yang dianjurkan dalam Islam juga telah dikenal masyarakat Jawa secara luas dengan bentuk sedekah laut, sedekah bumi dan sejenisnya, sebagai ungkapan terima kasih kepada Tuhan Yang Esa atas rezeki yag diperoleh.

Kata kunci: konstruksi, ayat-hadits, ekonomi, majalah, semiotik

\section{PENDAHULUAN}

MAJALAH merupakan salah satu media massa yang diyakini sebagian orang dapat memberikan pengaruh besar kepada masyarakat. Sebagai salah satu sumber informasi, keberadaan majalah hingga kini masih digemari oleh masyarakat. Seiring dengan semakin tingginya tingkat melek huruf penduduk Indonesia majalah dapat tumbuh dan subur, namun syarat melek huruf bukan satu-satunya faktor penentu untuk bertumbuhnya media massa yang oleh John Vivian disebut dengan istilah hot media. Hal ini, menurut Vivian disebabkan konsumsi orang terhadap media cetak bernama majalah ini membutuhkan konsentrasi yang lebih besar dan waktu yang khusus. Dengan kata lain orang mengkonsumsi majalah memerlukan keseriusan, perlu berpikir dengan lebih tenang dan fokus. Ini sangat berbeda dengan televisi yang digolongkannya sebagai cool media (Vivian 2008,16). Faktor penting lainnya adalah daya beli masyarakat. Biasanya negara yang memiliki pendapatan perkapita tinggi akan didapati banyak media cetak, seperti majalah dan surat kabar yang berkembang dengan baik. Dengan demikian tingkat ekonomi akan mendorong tingkat konsumsi media majalah/surat kabar.

Pada umumnya kelahiran majalah dilatar belakangi oleh beberapa hal, 1) kebutuhan masyarakat akan 
informasi yang lebih detil dan bersifat entertaint. Mengapa hal ini terjadi? Sebab meskipun telah banyak surat kabar beredar namun pada masyarakat tertentu masih memerlukan informasi yang bukan hanya sekedar news/berita. 2) sebagai industri yang bergerak di bidang penjualan informasi, tujuan utamanya adalah mencari keuntungan ekonomi. Meskipun secara tidak langsung juga akan mendapatkan keuntungan non material (seperti:banyak mendapatkan relasi dan dikenal oleh banyak orang, menyalurkan hobi/minat, sebagai" alat" perjuangan). 3) besarnya pangsa pasar membuat pemilik dan pengelola tergiur untuk mencoba peruntungan bisnis majalah. Terbukanya kesempatan bagi setiap warga negara Indonesia untuk menjalani bisnis media massa, hal ini sesuai dengan peraturan Undang Undang yang ada.

Dewasa ini telah banyak majalah yang terbit dan beredar di Indonesia ini. Ditinjau dari sisi daerah asalnya, pembagian majalah secara umum terbagi dua, majalah Indonesia dan majalah Luar Negeri. Kategori majalah Indonesia sudah sangat banyak, setidaknya ada sepuluh, yaitu: 1) Budaya, Sastra dan Seni. 2) Berita politik, bisnis dan ekonomi, 3) Ekonomi, keuangan, 4) Perindustrian, peratambangandanmaritim, 5)Agama, 6) Dakwah Islam, 7) Gaya Hidup, 8) Remaja, 9) Anak, 10) Komputer. Dari sekian banyak kategori diatas, yang sudah sangat dikenal khalayak diantaranya adalah: majalah Horison, majalah Tempo, majalah Gatra, majalah Marketing, majalah Sabili,
Majalah Suara Hidayatullah, majalah Dewi, Let's eat magazine, majalah Hai, majalah Bobo, majalah Info Komputer. Sedangkan majalah luar negeri, diantaranya adalah: majalah Forbes, majalah Time, majalah Hello, majalah Vogue Indonesia dan sebagainya. Kebanyakan majalah tersebut membidik segmen yang spesifik. Dengan segmen yang khusus pelayanan kepada pembaca menjadi lebih mudah.

Segmentasi menurut Morissan $(2008,168)$ diperlukan agar pengelola media dapat melayani pembacanya terfokus dan lebih baik. Kehadiran banyak jenis majalah di negara kita memberi alternatif pada masyarakat untuk mengkonsumsi sesuai dengan kebutuhan dan minatnya. Tentu saja hal ini menggembirakan karena selain membuka wawasan tentang hal baru juga banyak menanamkan nilai-nilai yang positif.

Salah satu jenis majalah yang banyak digemari masyarakat saat ini adalah majalah dakwah. Majalah ini secara ekonomi memiliki pangsa pasar yang sangat luas, mengingat jumlah penduduk muslim di Indonesia masih mayoritas. Data BPS menunjukkan bahwa penduduk Indonesia beragama Islam berjumlah sekitar $85 \%$ dari jumlah penduduk Indonesia. Di Indonesia, kemunculan majalah dakwah dimulai sekitar tahun 80-an dengan lahirnya majalah Sabili. Kemudian majalah Suara Hidayatullah yang terbit bulanan, dikelola oleh Pesantren Hidayatullah Surabaya. Juga majalah Media Dakwah yang diterbitkan oleh Dewan Dakwah 
Indonesia, yang beralamat di Jl Kramat Raya 45 Jakarta. Dari beberapamajalah dakwah tersebut terdapat kesamaan karakteristik. Menurut Ria Warda, karakteristik majalah dakwah adalah harus mengedepankan misi utamanya sebagai wadah penyampaian pesan dakwah. Jadi semua rubrik atau ruang pemberitaan, termasuk ruang opini, analisa, informasi, konsultasi, berita lokal -nasional-internasional, dll semuanya harus mencerminkan misi dakwah dengan tujuan utama sebagai penyampai pesan untuk menyadarkan sasaran dakwah (pembaca) sebagai hamba Allah sekaligus sebagai khalifah di muka bumi. Meski tak bisa dipungkiri, daya tarik majalah diantaranya karena konten yang bermutu dan seni /gambar yang ditawarkan. Namun dalam majalah dakwah, seni lebih ditujukan untuk moral akhlaqul karimah.

Nurul Hayat tergolong dalam majalah dakwah. Majalah dakwah memiliki karakteristik umum seperti laiknya majalah lain, ditambah dengan kekhasannya dalam cara bagaimana menyampaikan bahasa langit (bahasa yang berisi pesan-pesan Allah SWT) agar dimengerti dan dipatuhi oleh pembaca. Menerapkan prinsip amar makruf nahi munkar dalam upaya mengelola jurnalistik. Eksistensi majalah Nurul Hayat di tengah masyarakat memiliki riwayat dan tujuan yang unik. Kelahirannya tidak didorong oleh kepentingan profit duniawi sebagaimana menjadi motif utama para pebisnis media massa. Berawal dari keprihatinan semakin bertambahnya kaum lemah dan terpinggirkan (biasa disebut dengan kaum dhuafa) telah menggerakkan naluri Muhammad Molik pendiri Yayasan Nurul Hayat (Surabaya) untuk menolong mereka dengan cara menyadarkan umat muslim agar lebih taat kepada Sang Pencipta, Allah Subhanahu Wa Ta'ala. Ketaatan terhadap perintah Allah dan menjauhi segala hal yang dilarangNya adalah tujuan awalnya. Konten amar makruf nahi munkar ada di setiap berita dan artikelnya, termasuk pembahasan tentang ekonomi.

Menurut Suwiknyo $(2010,7)$ Islam memberikan keterangan yang jelas mengenai ekonomi dan kesejahteraan manusia, tidak hanya dalam kitab suci Alqur'an, namun juga dalam hadits rasulullah. Pemberdayaan umat sangat tepat bila dibarengi dengan penguatan ekonomi umat. Menurut Islam, kemiskinan merupakan problem serius yang harus diberikan perhatian secara serius pula. Karenanya, Islam menjelaskan masalah kemiskinan dan kesenjangan sosial ini secara detail, baik pada aspek konsepsi maupun solusinya.

Majalah dianggap sebagai mediator yang baik agar kaum aghniya lebih dekat dengan kaum dhuafa. Konten majalah Nurul Hayat mengingatkan saudara seiman untuk berbagi kekayaan, kepandaian dan kesukaan. Menguatkan mental yang inferior, memberikan inspirasi dan mensyukuri segala nikmat pemberianNya menjadi suatu hal indah yang ingin diraih.Yayasan Nurul Hayat berdiri tahun 2001 bergerak dalam bidang layanan 
sosial dan dakwah. Dalam mengelola majalah Nurul Hayat, pengelola tidak mengambil dana zakat dan sedekah ummat, Sebagaimana dikatakan oleh Molik :"Kami berusaha memenuhi gaji karyawan secara mandiri dari berbagai lini usaha. (http://www. nurulhayat.org. Diakses 23 februari 2015 jam 20.40). Berbekal tekad, Muhammad Molik beserta pengelola lainnya untuk menegakkan ajaran Islam, khususnya dalam menjembatani kaum kaya dan kaum miskin dengan semangat distribusi kekayaan yang lebih baik dan merata, menumbuhkan kepercayaan masyarakat kepada Nurul Hayat. Akhir 2014, pemerintah memberikan apresiasi Yayasan Nurul Hayat sebagai lembaga sosial nasional terbaik. Majalah NH dinilai bisa menjadi mediator umat Islam agar bisa bersatu memperjuangkan kesejahteraan masyarakat yang selama ini berjarak sangat curam jarak antara si kaya dan dhuafa.

Upaya memperjuangkan kesejahteraan dan keshalihan umat menjadi faktor pendorong untuk melakukan sesuatu. Pertanyaan besar yang muncul:Mengapa umat Islam yang memiliki ajaran agama terbaik yang pernah ada di muka bumi ini belum lagi bisa bangkit memperbaiki diri? Padahal teladan Nabi kita Muhammad SAW telah memberi contoh terbentuknya masyarakat madinah al munawarrah yang damai dan sejahtera. Pernah pula seorang Umar bin Abdul Azis (seorang yang mememiliki tauhid yang kuat) dimasa dinasti Umayyah, memimpin dengan menerapkan ajaran Islam yang diajarkan Nabi agung Muhammad SAW dan menghasilkan masyarakat yang makmur. Diceritakan dalam sejarah, bagaimana makmurnya penduduk kala itu dengan para amil zakat berkeliling di perkampunganperkampungan Afrika, tetapi mereka tidak menemukan seorangpun yang mau menerima zakat. Negara benarbenar mengalami surplus, bahkan sampai ketingkat dimana utang pribadi dan biaya pernikahan warga pun ditanggung oleh pemerintah/ negara.Sungguh sangat makmur dan nyaman serta bermartabat kehidupan masyarakat muslim ketika itu (Matta 2010, 252)

Jumlah umat muslim yang banyak di Indonesia nampaknya belum mampu memperbaiki keadaan negara kita yang diliputi berbagai masalah sebagaimana telah disebutkan diatas. Benarkah ini disebabkan oleh derasnya arus globalisasi, ataukah kompetisi media massa yang sangat ketat di bumi Nusantara ini justru menjadi ajang mencari profit para konglomerat dan melupakan tujuan mulia untuk menggunakan media massa (termasuk majalah) sebagai alat pendidikan, pendorong moralitas dan pemersatu bangsa? Majalah pada umumnya justru semakin banyak dan gencar menawarkan kemewahan dunia, mengagungkan kekuasaan dan menyebarkan virus kebebasan (termasuk free sex), politik yg sekuler dengan 'black campaign'nya.

Berlawanan arus dengan majalah yang demikian, Nurul Hayat sarat dengan potongan mozaik yang indah yang selalu ingin dihadirkan 
oleh redaksi untuk menawarkan empowerment di berbagai sudut pemberitaanmaupundalamartikelnya. Dakwah bil haal yang menjadi prioritas (berupa pengelolaan dana zakat, infaq dan shadaqah) disampaikan kepada mustahik. Tak hanya itu program sustainabel untuk meningkatkan potensi dhuafa dan orang-orang yang khusuk menghafal qur'an diutamakan , diberitakan secara terbuka untuk dimengerti oleh para donatur. Selain itu dalam majalah disisipkan ayat ayat al Qur'an maupun hadits yang terkait dengan tema majalah saat itu. Artikel ini ingin menjelaskan tentang bagaimanakah ayat-ayat dan hadits tentang ekonomi dikonstruksi dalam majalah Nurul Hayat.

\section{REVIEW PENELITIAN TERDAHULU}

Sebelum penulis melakukan penelitian ini, telah ada beberapa riset terdahulu mengenai majalah maupun konstruksi pesan, diantaranya sebagai berikut. Sierin HameliaHendry(2010), meneliti "Pengaruh Tampilan Fisik Model Perempuan Majalah Gogirl! Terhadap Body Image Remaja Putri SMA ST Thomas Aquino". Penelitian yang dilakukan merupakan survei kepada remaja puteri pembaca Gogirl di SMA tersebut menggunakan metode Structural Equation Modelling (SEM) dengan software SmartPLS, dimana metode tersebut cocok digunakan dalam penelitian eksplanatif dan mampu membuat sebuah model baru. Dalam hipotesanya, Hendry menyatakan: Tampilan fisik model perempuan majalah Gogirl! memiliki pengaruh terhadap body image.

Hasil penelitiannya adalah, besarnya pengaruh kecil dengan kekuatan hubungan pengaruh positif antara tampilan fisik model perempuan majalah Gogirl! terhadap body image responden.Teori Limited Effect yang berasumsi bahwa pengaruh media terhadap audien terbatas, relevan sebab pengaruhnya terbukti kecil. Pengaruh lainnya dapat berasal dari terpaan media lainnya, suasana hati, interaksi dengan teman /orang lain. Hubungan kekuatan yang terbentuk seharusnya negatif, tetapi data di lapangan menunjukkan positif. Hal tersebut bisa disebabkan oleh kemampuan media literacy yang dimiliki oleh responden yang memampukan mereka untuk mengkritisi tampilan fisik model.

Selanjutnya riset yang dilakukan oleh Farrel Corcoran (dalam Shobur 2001, 108) terhadap liputan di tiga majalah berita terkenal di Amerika Serikat: Time, Newsweek, dan US News and World Report mengenai penembakan pesawat komersial Korea Selatan oleh tentara Uni Soviet pada 1993. Sebagaimana diberitakan banyak media, kecelakaan pesawat tersebut mengakibatkan kematian pada seluruh penumpang KAL. Corcoran dalam simpulannya mengatakan bahwa ketiga majalah tersebut secara semiotis telah menggambarkan atau lebih tepatnya menjuluki Uni Soviet sebagai bangsa yang ignorant (bodoh), drab (kacau), politically sensitive (sensitif secara politis), tyranical (tiranik), dan barbaric (tidak berperadaban/liar). 
Kejadian tersebut menurutnya telah dimanfaatkan ketiga majalah tersebut sebagai condensational symbol/simbol perantara untuk menghadirkan atau mencitrakan Uni Soviet sebagai bangsa yang jahat. Perlu diketahui bahwa ketiga majalah Amerika melihat kejadian kecelakaan pesawat itu dari sudut pandang sebagai "musuh" Uni Soviet. Setidaknya, majalah tersebut telah tampil mewakili publik Amerika yang menjadikan dirinya sebagai agen virtual dari pemerintah Amerika.

\section{METODE PENELITIAN}

Tujuan dari penelitian yang dilakukan sebelumnya untuk memahami makna secara lebih mendalam terhadap konstruksi ayat dan hadits ekonomi dalam majalah Nurul Hayat melalui penelitian deskriptif kualitatif. Analisis yang digunakan dalam riset tersebut adalah semiotik. Semiotik merupakan suatu alat untuk menganalisis pesanpesan, cara tanda-tanda digunakan untuk menginterpretasikan peristiwa. Menurut Turnomo Raharjo (dalam makalah "Memahami Media", 2015), postulatutama semiotika mediaadalah: 1) pesan media dapat mengungkapkan beragam makna, 2) sebuah teks dapat dipahami dalam berbagai cara pula, 3) pesan-pesan media memperoleh maknanya melalui asosiasi-asosiasi yang dibuat oleh khalayak, dan 4) makna suatu pesan dipengaruhi oleh peristiwa di luar pesan itu sendiri.

Dari rubrik dan artikel yang terdapat dalam majalah dilakukan pemilahan atau kategorisasi sesuai kebutuhan. Selanjutnya dikaji lebih mendalam dengan menggunakan pendekatan semiotik, merujuk pada pendapat Roland Barthes. Prosedur yang dilakukan dalam analisis ini adalah melakukan pemilahan antara Signifier (penanda) dengan Signified (petanda). Signifier merupakan bunyi yang bermakna atau coretan yang bermakna. Ini merupakan aspek material, seperti apa yang dikatakan dan apa yang ditulis. Sementara itu, signified merupakan gambaran mental, yaitu pikiran atau konsep aspek mental dari bahasa. Mitos merupakan pengungkapan yang dikaitkan dengan nilai atau budaya yang dianut oleh leluhur.

Data penelitian berupa dokumen majalah Nurul Hayat edisi November 2014 (Muharram-Shafar 1436 H). Adapun rubrik yang sering terdapat muatan ayat dan hadits ekonomi adalah: Hikmah Utama, Nuansa Qalbu, Konsultasi Keluarga, Hikmah Al Qur'an, dan pemberitaan Inspirasi Keluarga. Rubrik tersebut dipilih sebab sering mengangkat tema ekonomi.

\section{PEMBAHASAN}

Majalah merupakan bagian pers. Disebutkan dalam Undang Undang No. 40 tahun 1999 tentang Pers, bahwa Pers adalah lembaga sosial dan wahana komunikasi massa yang melaksanakan kegiatan jurnalistik meliputi mencari, memperoleh, memiliki, menyimpan, mengolah dan menyampaikan informasi. Informasi dapat berwujud tulisan, suara, gambar, suara dan gambar, serta data dan grafik 
dan bentuk lainnya. Semua informasi dapat disebar dengan menggunakan media cetak, media elektronik dan segala jenis saluran yang tersedia

Oleh karena itu pers dalam bentuk media tercetak seperti majalah merupakan sub sistem dari sistem kemasyarakatan dimana ia berada, bersama-sama dengan sub sistem lainnya. Menurut Onong U. Effendi, "Pers tidak hidup secara sendiri, melainkan mempengaruhi dan dipengaruhi oleh lembagalembaga kemasyarakatan lainnya". Tumbuh dan berkembangnya pers sejalan dengan kebutuhan masyarakat terhadap informasi yang disajikannya, disamping kemampuan media pers mengelola industrinya dibidang informasi. Selain itu juga kultur masyarakat yang ingin maju. Pesan yang tersaji dalam majalah merupakan banyak peristiwa bernilai berita (mengandung news value) yang ingin disampaikan kepada khalayak luas, apa yang dibutuhkan oleh masyarakat, dan apa pula yang telah diberikan kepada masyarakat.

\section{PENGARUH MAJALAH \& LIMITED THEORY}

Majalah sebagai salah satu media massa konvensional diyakini bisa memberikan pengaruh kepada penggunanya. Jika di akhir tahun 1930-an sampai 1940 an media digambarkan sangat perkasa dan memiliki pengaruh yang sangat kuat terhadap penggunanya (sebagaimana asumsi dalam Hypodermic Needle Model), sudah sejak lama hal itu bergeser. Hal ini dimungkinkan karena semakin meratanya pendidikan pada masyarakat luas, sehingga orang yang sudah lebih pandai tidak begitu saja dengan mudah bisa dipengaruhi oleh media. Riset Bowan dan Davis memperkuat sinyalemen ini.

Stanley J. Bowan dan Jennis K. Davis mengartikan Limited Effect Theory dengan "views of media as having litle ability to directly influence people. The dominant effect of media is to reinforce existing social trends and strengthen the status quo".Teori efek terbatas dihasilkan dari penelitian yang menunjukkan bahwa setiap orang terlindungi dengan baik (were well protected) dari pengaruh media melalui pemuka pendapat/opinion leader yang menyaring propaganda komunis sebelum sampai kepada pengikutnya (https://books.google. $\mathrm{com} /$ books? isbn=1285972643. Diakses 25 Februari pukul 12.10)

Teori ini mengungkapkan bahwa manusia tidak dilihat sebagai individu yang tidak berpikir dan bukan merupakan korban penipuan dari media, tetapi individu dilihat aktif dan memiliki pemikiran. Menurut Baran (dalam Stanley J. Bowan dan Jennis K. Davis), faktor-faktor yang membatasi pengaruh media massa terhadap audien adalah:

1. Perbedaan idividu (intelegensi, edukasi)

2. Kategori sosial (agama, politik, pekerjaan)

3. Hubungan personal (teman, kelompok) 
Perbedaan individu akan menghasilkan pola perhatian yang berbeda dalam melihat konten media. Perbedaan individu seperti kepercayaan, ketertarikan, pengetahuan nilai-nilai ini akan membuat seseorang mempersepsikan stimulus secara berbeda. Interpretasi seseorang terhadap pesan di media massa juga berbeda tergantung pada konstruk kognisi mereka. Lalu seseorang akan masuk ke dalam kategori sosial tertentu memiliki interpretasi berbeda terhadap konten media. Miller berpendapat bahwa media yang memberikan pesan yang ditujukan untuk strata sosial/kelompok yang berkepentingan tertentu akan mempengaruhi sikap dan perilaku mereka.

Faktor yang ketiga adalah hubungan personal antara seseorang dengan teman dan keluarga akan lebih cenderung tertarik melihat isu atau topik yang sama. Lebih lanjut, hal tersebut dapat menjadi pengaruh yang kuat secara terarah. Bahkan hubungan sosial bisa menjauhkan perhatian seseorang kepada konten media yang tidak disukainya, tambah De Fleur dan Ball Rokeach.

\section{EKONOMI ISLAM}

Beberapa ahli mendefinisikan ekonomi Islam sebagai ilmu yang mempelajari perilaku manusia dalam usaha untuk memenuhi kebutuhan dengan alat pemenuhan kebutuhan yang terbatas di dalam kerangka syariah. Istilah ekonomi Islam seolah merupakan perpaduan dua pengertian: ekonomi (yang cenderung sekuler), dan ajaran Islam. Sementara itu bila dilihat dari sumber ajaran agama Islam, masalah pemenuhan kebutuhan manusia untuk mencapai kesejahteraan itu sudah termasuk dalam pembahasan Islam. Syariat Islam mengandung suatu tatanan nilai yang berkaitan dengan aspek akidah, ibadah, akhak dan muamalah. Pengaturan sistem ekonomipun tidak bisa dilepaskan dengan syariat Islam dalam pengertian yang lebih luas. Agar kita mendapat pemahaman yang lebih luas, berikut pendapat pakar:

Hasanuzzaman mengartikan ekonomi Islam sebagai ilmu dan aplikasi petujuk dan aturan syariah yang mencegah ketidakadilan dalam memperoleh dan menggunakan sumberdaya material agar memenuhi kebutuhan manusia dan agar dapat menjalankan kewajibannya kepada Allah dan masyarakat. Sementara itu Khan (dalam Yuliadi. 2001, 8) mendefinisikan ekonomi Islam sebagai suatu upaya memusatkan perhatian pada studi tentang kesejahteraan manusia yang dicapai dengan mengorganisasikan sumberdaya di bumi atas dasar kerjasama dan partisipasi. Allah SWT banyak menukilkan ayat bermakna ekonomi, baik berupa perintah zakat, infak maupun shadaqoh dalam kitab suci Al Qur'an karim serta al hadits. Selain itu larangan bagi umat muslim melakukan riba, karena akan sangat memberatkan dan menenggelamkan seseorang dalam kemiskinan.

Menurut Yuliadi $(2001,86)$, sistem ekonomi Islam memiliki beberapa 
prinsip dasar sebagai berikut:

1. Individu mempunyai ke-bebasan sepenuhnya untuk berpendapat/ membuat suatu keputusan yang dianggap perlu, selama tidak menyimpang dari kerangka syariat Islam untuk mencapai kesejahteraan masyarakat yang optimal dan menghindari kemungkinan terjadinya kekacauan dalam masyarakat.

2. Agama Islam mengakui hak milik individu dalam masalah harta sepanjang tidak merugikan kepentingan masyarakat luas.

3. Islam juga mengakui bahwa tiap individu pelaku ekonomi mempuyai perbedaan potensi yang juga memberikan peluang luas bagi seseorang untuk mengoptimalkan kemampuannya dalam kegiatan ekonomi. Sekaligus menghindari kemungkinan terjadinya konsentrasi kekayaan pada seseorang/sekelompok pengusaha dan mengabaikan kepentingan masyarakat umum

4. Islam tidak mengarahkan pada suatu tatanan masyarakat yang menunjukkan adanya kesamaan ekonomi, tapi mendukung dan menggalakkan terwujudnya tatanan kesamaan sosial.Tiap individu mempunyai peluang yang sama untuk mendapatkan pekerjaan dan melakukan aktivitas ekonomi

5. Adanya jaminan sosial bagi tiap individu dalam masyarakat. Negara wajib menjamin setiap warganya dalam memenuhi kebutuhan pokok hidupnya.

6. Islam melarang penimbunan kekayaan secara berlebihan yang dapat merusak tatanan perekonomian masyarakat. Pelaku penimbunan diberikan sanksi yang keras.

7. Islam tidak mentolerir terhadap praktek asosial dalam kehidupan, seperti: minum minuman keras, perjudian, prostitusi, peredaran pil ekstasi, pornografi, night club, discotik,dll

\section{KONSTRUKSI AYAT DAN HADITS TENTANG EKONOMI}

Seiring dengan perkembangan informasi yang semakin pesat, bentuk-bentuk penyampaian pesan dimana kegiatan dakwah termasuk didalamnya, juga perlu dimodernisir agar sesuai dengan perkembangan zaman. Jika ini tidak dilakukan, maka sistem difusi informasi atau penyebara pesan dalam bentuk dakwah akan tertinggal dan dapat berakibat tidak lagi mendapat tempat yang memadai/ layak di tengah kemajuan ilmu dan teknologi. Dengan demikian ruang pemberitaan yang kelak dikonsumsi pengguna menjadi alternatif untuk menyebar luaskan ajaran agama Islam.

Ruang pemberitaan tidak dipandang sebagai ruang hampa karena banyak kepentingan dan pengaruh yang dapat mengintervensi media. Apa yang disajikan media massa pada dasarnya adalah akumulasi dari berbagai macam pengaruh. Pamela J Shoemaker dan Stephen D Reese sebagaimana dikutip 
Sudibyo (2001,39) menyebutkan ada lima faktor yang mempengaruhi pengambilan keputusan dalam pemberitaan, diantaranya: 1) faktor individual (seperti jenis kelamin, usia, agama), 2) faktor rutinitas media (mekanisme dan proses penentuan berita), 3) faktor organisasi (struktur organisasi), 4) faktor ekstramedia (sumber berita, sumber penghasilan berita, pihak eksternal dan lingkungan bisnis dan ideologi)

Kehadiran pesan dalam suatu media massa bersifat tidak netral melainkan dikonstruksi untuk sistem kognitif. Individu menginterpretasikan dan beraksi menurut kategori konseptual dari pikirannya. Fenomena yang terjadi di dunia dapat dipahami dengan cara berbeda oleh setiap individu. Konstruktivisme tidak bertujuan mengerti realitas, tetapi lebih melihat bagaimana kita menjadi tahu akan sesuatu karena realitas terbentuk secara visual. Konstruktivisme dalam ilmu komunikasi mengalami perkembangan melalui penelitian ilmiah, seperti analisis wacana dan semiotik.

Sesuai dengan tujuan kegiatan jurnalistik, keindahan sajian produknya sangat diutamakan. Indah dalam arti diminati dan dinikmati, karena itu berita perlu disajikan dengan konstruksi tertentu. Menurut Suhandang (2016:123), keseluruhan bangunan naskah berita terdiri atas tiga unsur, yaitu: headline (judul berita), lead (teras berita), dan body (kelengkapan atau penjelasan berita). Headline hakikatnya merupakan intisari dari berita. Diibuat dalam satu atau dua kalimat pendek, namun cukup memberitahukan persoalan pokok peristiwa yang diberitakannya. Agar menarik, headline dibuat tidak seragam, agar masing-masing berita dapat ditonjolkan lain dari yang lainnya. Misalnya: jenis, ukuran, serta penyusunan hurut atau katakatanya. Fungsi utama headline adalah memanggil khalayak agar mau membaca, atau minimal tahu apa yang menjadi pokok pemberitaannya.

Menurut kepentingan berita, dikenal empat jenis headline (Suhandang,2016:124):

1. Banner headline, untuk berita yang sangat atau terpenting. Headline dimaksud dibuat dengan jenis dan ukuran huruf yang mencerminkan sifat gagah dan kuat, dalam arti hurufnya terbesar dan lebih tebal ketimbang jenis headline lainnya, serta menduduki tempat lebih dari empat kolom surat kabar.

2. Spread headline, untuk berita penting. Headline dimaksud tampak lebih kecil dibanding jenis Banner headline. Tempat yang diperlukan sekitar tiga atau empat kolom

3. Secondary headline, untuk berita yang kurang penting. Ukurannya lebih kecil dibanding Spread headline, dan memerlukan tempat dua kolom.

4. Subordinated headline, untuk berita yang dianggap tidak penting. Kehadiran berita yang ada dalam kategori ini, kadang-kadang dibutuhkan 
untuk menutup tempat yang kosong pada halaman yang bersangkutan. Kosong dalam arti sisa tempat pada halaman yang memuat berita-berita lain yang dianggap kurang penting sampai dengan yang terpenting. Tempat yang diperlukan satu kolom saja dengan ukuran huruf dan ketebalan yang lebih rendah dibanding jenis lainnya.

Adapun terkait keserasian baris (deck), dikenal enam bentuk headline, yaitu:

1. Cross line, yaitu headline yang terdiri dari satu deck (atau sebaris kata)

2. Pyramid headline, yaitu headline yang lebih dari satu deck dan disusun seperti piramid

3. Inverted headline, yaitu headline yang terdiri dari beberapa deck (beberapa baris kata) dan disusun sedemikian rupa sehingga membentuk piramida terbalik

4. Jump headline, yaitu headline yang dipergunakan sebagai judul dari sambungan berita yang ditempatkan di halaman lain. Biasanya cukup dengan kata awal dari judul aslinya.

Lead (teras berita) merupakan sari dari berita. Disusun secara ringkas, sehingga bisa menjawab pertanyaan seputar $5 \mathrm{~W}+1 \mathrm{H}$. Dengan hanya membaca lead, pembaca akan segera tahu persoalan pokok dari peristiwa yang dilaporkan jurnalis.

Bagian penting dalam berita yang selanjutnya adalah Body. Body merupakan keterangan secara detil/ rinci dan bersifat memerjelas fakta atau data yang disuguhkan dalam lead. Biasanya body ini ditulis dalam bentuk Inverted Pyramid/ piramida terbalik. Keterangan yang disajikan dalam bentuk uraian cerita dan gambar dengan menggunakan gaya penyampaian yang bisa memikat pembaca

Dalam majalah Nurul Hayat, konstruksi berita maupun artikel secara keseluruhan mengedepankan misi utamanya sebagai wadah penyampaian pesan dakwah. Jadi semua rubrik ataupun ruang pemberitaan, termasuk ruang opini, analisa, informasi, kosultasi, berita lokal, dll semuanya mencerminkan misi dakwah dengan tujuan utama sebagai penyampai pesan untuk menyadarkan sasaran dakwah (dalam hal ini pembaca) sebagai hamba Allah sekaligus sebagai khalifahNya.

\section{TEMUAN PENELITIAN}

Majalah Nurul Hayat (berukuran $16 \mathrm{~cm} \times 24 \mathrm{~cm}$ dengan tebal 3 milimeter, 61 halaman) dalam mengkonstruksi berita maupun rubrik/ artikel didalamnya menerapkan pola informasi Islami, menggunakan sumber yang jelas, rujukan yang tepat dan gaya penyampaian yang santun. Dalam menciptakan tandatanda, baik berupa kata-kata maupun kalimat ataupun gambar pendukung di dalam rubrik dan artikel yang ada dipilih dengan teliti. Beberapa konten didalamnya adalah artikel dan rubrik yang bermanfaat untuk seluruh 
anggota keluarga sejuk Nurul Hayat (Dewasa, remaja dan anak).Hikmah Utama, Mutiara Hadits, Hikmah Al Qur'an, Konsultasi Agama, Islam dan Sains, Griya Islami, Dokter menjawab, Rindu Baitullah, Khazanah, BagiBagi,Generasi Emas, Sakinah, Kisah Hikmah, Inspirasi Keluarga dan Nuansa Qalbu merupakan rubrik yang tergolong Dewasa, namun juga cocok dibaca untuk Semua Umur (karena tidak disajikan dengan vulgar), hanya konten probematikanya untuk konsumsi usia dewasa. Kemudian, Islam Gue Banget, Cerita Remaja, Buat Nanda, Rehat, Kisah Hidayah ,dan Cermin merupakan rubrik untuk Remaja. Sedangkan rubrik: English Arabic Corner, Karyaku, Karcis, Cerpen Anak, Teka Teki, Asyiknya Menggambar ditujukan untuk AnakAnak.

Dalam edisi 130, Majalah Nurul Hayat mewacanakan Sedekah Subuh. Beberapa hadits riwayat Bukhari menjadi rujukan dalam artikel bertema Sedekah Subuh ini. Selain itu ayat yang menjadi rujukan nara sumber (Syeh Ali Jaber) adalah al Ashr ayat 1-3 serta al Munafiqun ayat 10. Dari cover majalah (luar dan dalam) diperoleh signifier berikut: tulisan besar berbentuk Banner Headline SEDEKAH SUBUH Karena ada doa malaikat di setiap Subuh: Tidak ada satu Subuh pun yang dialami hamba-hamba Allah kecuali turun kepada mereka dua malaikat, salah satu diantara keduanya berdo'a: Ya Allah, berilah ganti bagi orang yang berinfaq." Sedangkan yang satu lagi berdo'a:"Ya Allah, berilah kerusakan bagi orang yang menahan (hartanya)" (HR.Bukhari). Kesan yang diperoleh (signified) dari visualisasi suasana pagi hari saat mentari terbit dengan pancaraan sinar kuning keemasan menerangi alam raya, agar manusia senantiasa memberi sesuatu atau bersedekah di awal hari. Sebagaimana Allah Sang Pencipta manusia serta alam seisinya telah memberikan rahmat yang tak pernah habis untuk kehidupan manusia. Sedekah merupakan salah satu amalan yang sangat utama kedudukannya dalam Islam, bahkan dalam ayat $10 \mathrm{SQ}$ al Munafiqun, Allah SWT berfirman: “...Ya Allah, tundalah kematian, kembalikan aku kedunia supaya aku bisa bersedekah..." Sedekah itu luar biasa, bahkan saking indahnya Allah berikan satu pintu surga, Baabus Shadaqah". Saya (Syeh Ali Jaber) ajak Bapak/Ibu untuk komitmen melakukan sedekah subuh, karena ada doa malaikat dan doa rasul bagi orang yang berinfaq setiap subuh. Posisikan kotak sedekah subuh anda di lokasi yang bisa anda lihat. Ibu/ Bapak silahkan taruh kotak di depan cermin, sebab setiap mau keluar biasa bercermin. Pesan ini juga bersifat preskriptif, membimbing seseorang untuk mudah melakukan kebaikan.

Ayat ayat suci al Qur'an yang relevan dengan tema kebanyakan ditulis dengan huruf Latin dan diberikan penjelasan makna dalam Bahasa Indonesia, serta gaya penyampaian yang sederhana. Namun hadits juga ditulis dalam bentuk tulisan Arab (asli). Dengan demikian terkesan bahwa pesan tidak mengungkapkan 
beragam makna, namun menjurus atau fokus pada satu pemahaman. Selain itu, ayat ayat dan hadits tentang ekonomi yang dituliskan diperkaya dengan ilustrasi tausiyah dai yang telah dikenal dan memiliki kredibilitas. Dengan demikian makna pesan ayat dan hadits ekonomi juga dipengaruhi oleh peristiwa di luar pesan itu sendiri. Sebagaimana terlihat sebagai berikut:

Dijelaskan pula oleh Syeh Ali Jaber tentang amal perbuatan manusia yang sangat mudah dilakukan dan fleksibel pelaksanaannya adalah sedekah. Dari aspek mitos, kebaikan berupa sedekah juga lazim dilakukan oleh leluhur kita, terutama untuk memulai suatu kegiatan yang besar, seperti: memulai tanam padi, membuat rumah, kelahiran seorang anak, mau menikahkan putra/i nya. Sedekah merupakan suatu bentuk pemberian seseorang yang bisa materi atau non materi, seperti: ilmu yang bermanfaat, bantuan tenaga, bantuan waktu, bimbingan rohani, memberi makan hewan, dan sebagainya.

Kehadiran majalah Nurul Hayat di masyarakat membawa misi yang berbeda dengan majalah profit lain. Konstruksi pesan dalam majalah menarik bagi anak maupun orang dewasa membacanya. Kemampuannya untuk menyebarkan pesan dan menghimpun dana masyarakat sebanyak sekitar 75.000 donatur tetap setiap bulannya merupakan bukti keberhasilannya. Adapun beragam materi yang ada didalam majalah ini mampu menarik minat kalangan masyarakat luas untuk bergabung menjadi donatur di Nurul Hayat.

\section{PENUTUP}

Majalah Nurul Hayat dalam mengkonstruksi berita maupun rubrik/ artikel didalamnya menerapkan pola informasi Islami, menggunakan sumber yang jelas, rujukan yang tepat dan gaya penyampaian yang santun. Tanda-tanda, baik berupa kata-kata, kalimat ataupun gambar pendukung di dalam rubrik dan artikel yang ada diciptakan dan dipilih dengan teliti. Pesan yang disajikan juga bersifat preskriptif, membimbing seseorang untuk mudah melakukan kebaikan. Dengan demikian pesan yang dinyatakan dalam bentuk kata-kata maupun gambar yang ada memiliki kekuatan untuk mendorong dan memberikan tenaga bagi pembaca mengikutinya, ke arah kemanfaatan individual dan sosial. 


\section{DAFTAR PUSTAKA}

Bowan, Stanley J.Jennis K Davis. Mass Communication Theory: Foundation, Ferment \& Future (seventh edition). http://books.google. $\mathrm{com} /$ books? isbn=1285972643. Diakses 25-2-15 pukul 12.10 WIB.

Hendry, Sierin Hamelia. "Pengaruh Tampilan Fisik Model Perempuan Majalah Gogirl Terhadap Body Image Kalangan Remaja Puteri SMA ST Thomas Aquino. http//books.google.com/ books? isbn $=9791583056$. . yeyond Borders: Communications Modernity and History. Dalam Communication Research Conference Proceeding. Diakses 25-2-2015 pukul 11.45 WIB

https://muslim.or.id/26166majalah-gratis-kabar-dakwah-edisizulhijah.html, akses 27 Agustus 2016

http://altajdidstain.blogspot. com/2011/02/majalah-sebagai-mediadakwah.html, akses 27 Agustus 2016

Majalah Nurul Hayat (NH News)-suplemen. edisi 26. Februari 2015

Majalah Nurul Hayat edisi 133. Februari 2015

Matta, M Anis. 2010. Dari Gerakan ke Negara: sebuah rekonstruksi negara Madinah yang dibangun dari bahan dasar sebuah gerakan.Bandung: Fitrah Rabani

Morissan.2008. Manajemen Media Penyiaran: Strategi Mengelola Radio dan Televisi.Jakarta: Kencana

Muladi, Edi. Semiotika Dalam Perancangan (modul 5).Pusat
Pengembangan Bahan Ajar UMB. kk.mercubuana.ac.id//12017-5 -891476954310.diakes 6 April 2015 pukul 09.53 WIB

Mulyana, Dedy, Ilmu Komunikasi: Suatu Pengantar.2008. Bandung: Remaja Rosda Karya

http://www.nurulhayat.org.

Raharjo, Turnomo.Memahami Media (makalah dalam Workshop Pola Penyiaran Agama Melalui Radio, diselenggarakan oleh Balitbang Kemenag Semarang, 10 Oktober 2015)

Shobur, Alex.2001. Analisis Teks Media: Suatu Pengantar untuk Analisis Wacana, Analisis Semiotik dan Analisis Framing. Bandung: Remaja Rosdakarya

Sudibyo. 2001. Politik Media dan Pertarungan Wacana. Yogyakarta: Pustaka Pelajar

Sugiyono.2005. Memahami Penelitian Kualitatif. Bandung: Alfabeta

Suhandang, Kustadi, 2016 (cetakan II) Pengantar jurnalistik: Seputar Organisasi, Produk dan Kode Etik, Bandung: Nuansa Cendekia

Suwiknyo, Dwi.2010. Kompilasi Tafsir Ayat Ayat Ekonomi Islam. Yogyakarta: Pustaka Pelajar.

Undang Undang No.40 tahun 1999 tentang Pers

Vivian, John.2008.Teori Komunikasi Massa ( edisi kedelapan). terjemahan Tri Wibowo.Jakarta: Kencana

Warda, Ria. Majalah Sebagai 
Kontruksi Ayat-Hadits Ekonomi di Media Cetak .... hal. 3-18

Media Dakwah, Jurnal Al Tajdid

STAIN Palopo,http://altajdidstain.

blogspot.com/2011/02/majalahsebagai-media-dakwah.html

Yuliadi, I m a mudin. 2001.

Ekonomi Islam Sebuah Pengantar.

Yogyakarta: Lembaga Pengkajian dan

Pengamalan Islam (LPPI) UMY. 